\title{
Intrapelvic Causes of Sciatica: A Systematic Review
}

\author{
[D Ahmet Kale,' (1) Betül Kuru,' (1) Gülfem Başol,' (1) Elif Cansu Gündoğdu,

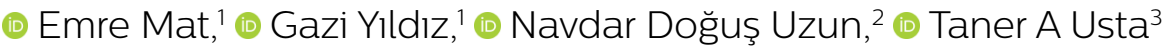

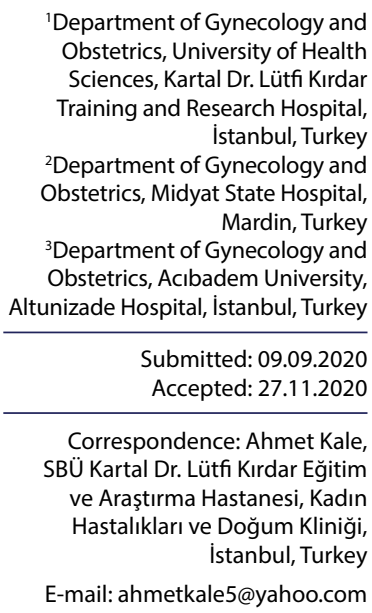

'Department of Gynecology and Obstetrics, University of Health Sciences, Kartal Dr. Lütfi Kırdar Training and Research Hospital, İstanbul, Turkey ${ }^{2}$ Department of Gynecology and Obstetrics, Midyat State Hospital Mardin, Turkey ${ }^{3}$ Department of Gynecology and Obstetrics, Acıbadem University, Altunizade Hospital, İstanbul, Turkey

Submitted: 09.09.2020 Accepted: 27.11.2020

Correspondence: Ahmet Kale, SBÜ Kartal Dr. Lütfi Kırdar Eğitim ve Araştırma Hastanesi, Kadın Hastalıkları ve Doğum Kliniği, İstanbul, Turkey

E-mail: ahmetkale5@yahoo.com

口frop

Keywords: Endometriosis; intrapelvic cause; pain; schwannoma; sciatica.

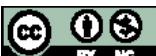

This work is licensed under a Creative Commons Attribution-NonCommercial 4.0 International License.

\begin{abstract}
The sciatic nerve is the nerve of the lower limb. It is derived from spinal nerves, fourth Lumbar (L4) to third Sacral (S3). The sciatic nerve innervates the muscles of the posterior thigh and additionally has sensory functions. Sciatica is the given name to the pain sourced by irritation of the sciatic nerve. Sciatica is most commonly induced by compression of a lower lumbar nerve root (L4, L5, or SI). Various intrapelvic pathologies include gynecological, vascular, traumatic, inflammatory, and tumoral disorders that may cause sciatica. Intrapelvic pathologies that mimic disc herniation are quite always ignored. Surgical approach and a functional exploration by laparoscopy or robotic surgery have significantly increased the intrapelvic pathology's awareness, resulting in sciatica. After a detailed assessment of the patient, which causes intrapelvic pathologies, deciding whether surgical or medical therapy is needed, notable results in sciatic pain remission can be done.
\end{abstract}

\section{INTRODUCTION}

The sciatic nerve is the nerve of the lower limb. It is the longest nerve in the body and approximately $2 \mathrm{~cm}$ wide. It is derived from spinal nerves L4 to S3. The sciatic nerve innervates the posterior thigh muscles and besides has sensory functions of the skin of the lateral leg, heel and whole foot.

Sciatica is the name given to pain caused by the sciatic nerve's irritation. Sciatica is manifested by searing pain down the leg from the lower back along the sciatic nerve path. Sciatica ordinarily affects only one side of the body and can be a result of an underlying injury. Most frequently, sciatica is due to compression of a lower lumbar nerve root $(\mathrm{L} 4, \mathrm{L5}$, or $\mathrm{SI})$ that radiates to the knee and is often accompanied by weakness or numbness of the respective myotome or dermatome.
Many intraspinal or extraspinal pathological disturbances along the sciatic nerve can be the reason for sciatica. Extraspinal sciatica is often misdiagnosed because routine diagnostic tests focus on the lumbar spine. Various intrapelvic pathologies include gynecological, vascular, traumatic, inflammatory and tumoral disorders may lead to sciatica. Another source of intrapelvic sciatica reported in the literature is endometriosis. Endometriosis is a common gynecological condition, described as the occurrence of endometriotic tissue (endometrial glands, stro$\mathrm{ma}$, or both) outside the uterus. However, endometriosis reports involving the sciatic nerve are mostly from direct extension of deeply infiltrative rectovaginal disease through the lateral pelvic sidewall. Schwannoma is the most prevalent benign nerve sheath tumor that causes sciatica and may be seen as presacral or retroperitoneal tumors in the pelvis. 
Sciatica with or without neurologic deficit has a high prevalence in the general population. The classic diagnostic workup focuses on pathologies of the spinal cord. When the absence of spinal pathologies is present, treatment is often very limited. Intrapelvic pathologies that mimic disc herniation are quite always skipped. Surgical approach and a functional exploration by laparoscopy or robotic surgery have significantly increased the intrapelvic pathology's awareness, resulting in sciatic pain.

In the present review, we reviewed the current literature regarding the intrapelvic causes of sciatica in various pathological conditions and discussed its management.

\section{MATERIALS AND METHODS}

A systematic literature search was performed in the Pubmed database using medical terms, keywords and their combinations, including "sciatica", "intrapelvic cause", "laparoscopy" and "gynecologic surgery" dating from its inception to Sep 2019. The bibliographies of all publications were searched for relevant references. Extracted data were both clinical outcomes and operative techniques. The following information, including publication date, sample size, patient characteristics, surgical procedures and clinical outcomes, were recorded. Many relevant data were extracted concerning intrapelvic causes of sciatica. A total of 22 articles were found to include intrapelvic causes of sciatica.

\section{RESULTS}

Our literature search yielded 22 studies with 120 cases related to intrapelvic causes of sciatica (Table I). ${ }^{[1-22]}$ In 1962, I case $^{[22]}$ was published followed by I in 1976, ${ }^{[21]} 2$ in $1987,{ }^{[19,20]} 1$ in $1994,,^{[18]} \mid$ in $1995,{ }^{[17]} 2$ in $1996,,^{[15,16]} 5$ in $1998,,^{[14]} 5$ in $1999,{ }^{[11-13]} \mathrm{I}$ in $2001,{ }^{[10]} 25$ in $2002,{ }^{[9]} \mathrm{I}$ in $2003,{ }^{[8]} \mathrm{I}$ in $2012,{ }^{[7]} \mathrm{II}$ in $2015,{ }^{[6]} 3$ in $2016,,^{[4,5]} 46$ in $2017,,^{[3]}$ 14 to date in $2019,{ }^{11,2]}$ The surgical procedures included 27 laparoscopic decompression of aberrant intrapelvic veins, 53 intrapelvic sciatic nerve (sacral nerve root) endometriosis excisions, one myomectomy, three hysterectomies, two schwannoma resections, one ovarian cystic endometriosis surgery, six endometriotic nodule excisions, 15 pelvic peritoneal pockets excisions, five peritoneal endometriosis excisions. The medical therapy included three gonadotropinreleasing hormone agonist $(\mathrm{GnRH}-\mathrm{A})$, leuprolide acetate plus daily transdermal E2 treatment, one depot medroxyprogesterone treatment, one buserelin acetate, one estrogen suppression treatment, and one gentamicin and clindamycin treatment (Table I). In the present review, we analyzed the current literature related to the intrapelvic causes of sciatica in various pathological conditions and discussed its therapy and management.

\section{Aberrant intrapelvic veins and sciatica}

Possover et al. ${ }^{[6]}$ reported the first case series of pelvic neuralgias by neuro-vascular entrapment treated by lapa- roscopic decompression. The most common is L5-SI sciatica. Eleven consecutive patients suffered from non-neurogenic L5/SI-sciatica; only $36 \%$ from an S2 complained of sciatica with some pain in pudendal areas (mostly perianal/ perineal pain).

After neuropelveological workup, pelvic neuro-Magnetic Resonance Imaging (MRI) and Doppler-sonography pelvic nerves were suspected to be implicated in pain. Laparoscopic exploration revealed compression of the distal portion of the lumbosacral trunk between the linea terminalis and enlarged varicose veins or the sciatic nerve just before its entry through the great sciatic notch. Enlarged varicose veins had typical superior and inferior varicose veins located in the lumbosacral space. Laparoscopic treatment consisted of the separation of the vessels from the nerves and coagulation or transection of them. They found that laparoscopic decompression of aberrant pelvic vessels was a treatment of choice in patients with intrapelvic sciatica. The laparoscopic approach gave the possibility of reduced morbidity and improved results by providing more comprehensive insight into the operating field with a smaller intraoperative injury. Lemos et al. ${ }^{[1]}$ described their initial experience in 13 women who presented with sciatica in the absence of any apparent spinal or musculoskeletal lesions. Pelvic MRI neurography visualized superior gluteal veins (SGV). Laparoscopy discovered compression of the lumbosacral nerve roots by aberrant SGV. The average time from onset of symptoms to diagnosis was 3.88 \pm 3.09 years. All cases that had a variant SGV were ligated laparoscopically. The mean operative time was $144.54 \pm 55.10$ $\mathrm{min}$. The average preoperative VAS score $(9.62 \pm 0.77)$ decreased significantly $(2.54 \pm 2.88)$ postoperatively. The laparoscopic approach alleviated symptoms with a statistically significant decrease in VAS pain scores and has a $92.3 \%$ success rate. It strongly supports the hypothesis that superior gluteal vein variant entrapment against the LS plexus resulted in the intrapelvic cause of sciatica's clinical presentation. Kale et al. ${ }^{[2]}$ demonstrated their clinical experience in a 26-year-old patient who had failed medical therapy and presented with persistent sciatica complaints on the right side of her lower limbs for approximately 36 months. The laparoscopic approach gave the possibility of decompression of the vessels' malformed branches entrapping the sacral plexus nerves at three sites: the lumbosacral trunk, sciatic nerve, and pudendal nerve. The laparoscopic approach was completed successfully with a resolution of dyspareunia and sciatica at a 6-months follow-up. They found that laparoscopic management of vascular entrapment of the sacral plexus was a feasible and effective technique in patients with intrapelvic sciatica. Lemos et al. ${ }^{[19]}$ reported two cases with catamenial sciatica and urinary symptoms who underwent laparoscopic decompression of intrapelvic aberrant dilated veins on the sciatic nerve and sacral nerve roots. Patients with catamenial sciatica showed full recovery with resolution of symptoms. Lemos et al. emphasized that in the presence of sciatic or perineal pain radiating to the lower limbs in the absence of a spinal disorder and lower urinary tract symptoms; the 
Table I. Patient characteristics and diagnostic methods of studies included in this review

\begin{tabular}{|c|c|c|c|c|}
\hline Authors & Country & $\mathbf{N}$ & Patient characteristics & Diagnostic methods \\
\hline Lemos et al. $2019^{[1]}$ & Switzerland & 23 & $\begin{array}{l}\text { All patients had a variant superior gluteal } \\
\text { vein syndrome with sciatica. }\end{array}$ & $\begin{array}{l}\text { Based on clinical neuropelveological and } \\
\text { urodynamic assessment. }\end{array}$ \\
\hline Kale et al. $2019[2]$ & Turkey & I & $\begin{array}{l}\text { A } 26 \text {-year-old patient presented with } \\
\text { complaints of persistent sciatica and } \\
\text { pudendal neuralgia. }\end{array}$ & Neuropelveologic examination and MRI. \\
\hline Possover et al. $2017^{[3]}$ & Switzerland & 46 & $\begin{array}{l}\text { All patients presented with incapacity for } \\
\text { normal gait and foot drop. All patients } \\
\text { were suffering from intractable and } \\
\text { constant neuropathic sciatic pain with } \\
\text { sensorimotor disorders of the affected leg. }\end{array}$ & $\begin{array}{l}\text { Preoperative neuropelveologic workup, } \\
\text { neurologic history and examination with } \\
\text { particular attention to symptoms for } \\
\text { lumbosacral radiculopathy. }\end{array}$ \\
\hline Tsai et al. $2016^{[4]}$ & Switzerland & I & $\begin{array}{l}\text { A 62-year-old postmenopausal woman } \\
\text { complained of left sciatic pain from broad } \\
\text { ligament leiomyoma. }\end{array}$ & $\begin{array}{l}\text { Serum level of cancer antigen (CA)- } 125 \text {, } \\
\text { computed tomography (CT) scan, a pelvic } \\
\text { ultrasound (US). }\end{array}$ \\
\hline Lemos et al. $2016^{[5]}$ & Brazil & 2 & $\begin{array}{l}\text { Two cases had catamenial sciatica and } \\
\text { urinary symptoms. }\end{array}$ & $\begin{array}{l}\text { Magnetic Resonance Imaging (MRI) } \\
\text { and pelvic ultrasonography with bowel } \\
\text { preparation. }\end{array}$ \\
\hline Possover et al. $2015^{[6]}$ & Switzerland & 11 & $\begin{array}{l}\text { Compression of the distal portion of } \\
\text { the lumbosacral trunk between the linea } \\
\text { terminalis and enlarged varicose veins } \\
\text { and/or the sciatic nerve just before its } \\
\text { entry through the great sciatic notch. All } \\
\text { these patients suffer from non-neurogenic } \\
\text { L5/SI-sciatica. }\end{array}$ & Pelvic neuro MRI, Doppler sonography. \\
\hline Lemos et al. $2012^{[7]}$ & Brazil & I & $\begin{array}{l}\text { 38-year-old woman had a sacral nerve } \\
\text { infiltrative endometriosis presenting as } \\
\text { perimenstrual right-sided sciatica and } \\
\text { bladder atonia. }\end{array}$ & Neurologic examination, MRI. \\
\hline Tong et al. $2003^{[8]}$ & Australia & 1 & $\begin{array}{l}\text { Patient had a history of right-sided } \\
\text { sciatica secondary to retroperitoneal } \\
\text { pelvic schwannoma. }\end{array}$ & MRI. \\
\hline Vilos et al. $2002^{[9]}$ & England & 25 & $\begin{array}{l}25 \text { women with a history of cyclic (sciatic) } \\
\text { leg pain radiating to the leg (right I5, left } \\
9 \text {, both I). }\end{array}$ & $\begin{array}{l}\text { Undetermined imaging modalities for } \\
\text { neurologic lesions. }\end{array}$ \\
\hline Murata et al. $200 I^{[10]}$ & China & 1 & $\begin{array}{l}\text { A } 47 \text {-year-old woman complained of } \\
\text { pain and numbness in the right calf and } \\
\text { weakness of the tibialis anterior muscle. } \\
\text { An unusual cause of sciatic pain was due } \\
\text { to compression of sacral nerve roots } \\
\text { by the uterus, which also had a small } \\
\text { myoma-like lesion. }\end{array}$ & $\begin{array}{l}\text { MRI, myelography, CT Myelography, } \\
\text { electromyography (EMG) (revealed an } \\
\text { abnormal voluntary action potential in } \\
\text { the ventral roots of } \mathrm{L} 5, \mathrm{SI} \text { and } \mathrm{S} 2 \text { ). }\end{array}$ \\
\hline Fedele et al. I999[II] & Italy & 3 & $\begin{array}{l}\text { Two patients had a history of catamenial } \\
\text { left-sided sciatica, and one patient had a } \\
\text { history of right-sided sciatica with pelvic } \\
\text { endometriosis. }\end{array}$ & $\begin{array}{l}\text { EMG, pelvic MRI performed in both the } \\
\text { menstrual and ovulatory phases. }\end{array}$ \\
\hline Siera et al. $1999{ }^{[12]}$ & Cuba & I & $\begin{array}{l}\text { Patients had a history of bilateral cyclic } \\
\text { sciatica caused by endometriosis. }\end{array}$ & $\begin{array}{l}\text { The clinical, imaging and electrophysiological } \\
\text { findings. }\end{array}$ \\
\hline Bodack et al. $1999^{[13]}$ & USA & I & $\begin{array}{l}55 \text {-yr-old woman with a history of sciatic } \\
\text { pain presented with progressive right } \\
\text { buttock and posterolateral right lower } \\
\text { limb pain. An MRI of the pelvis revealed } \\
\text { a markedly enlarged uterus, with a large } \\
\text { pedunculated myoma impinging on the } \\
\text { right sciatic foramen. }\end{array}$ & Lumbosacral and pelvic MRI. \\
\hline
\end{tabular}


Table I. Patient characteristics and diagnostic methods of studies included in this review (continue)

\begin{tabular}{|c|c|c|c|c|}
\hline Authors & Country & $\mathbf{N}$ & Patient characteristics & Diagnostic methods \\
\hline Zager et al. $1998^{[14]}$ & USA & 5 & $\begin{array}{l}\text { Patients had a history of catamenial } \\
\text { mononeuropathy with left-sided sciatica } \\
\text { involving the left sciatic and femoral nerves } \\
\text { and multiple lumbosacral nerve roots. }\end{array}$ & Pelvic CT, MRI, and EMG. \\
\hline Ortolan et al. 1996[15] & Argentina & I & $\begin{array}{l}\text { Patient had a history of right sciatica with } \\
\text { large sacral schwannomas with anterior } \\
\text { cortex erosion and intrapelvic extension. }\end{array}$ & $\begin{array}{l}\text { Myelogram, radiologic films, CT, 3D CT, } \\
\text { MRI, Radionuclide bone scan, CT-guided } \\
\text { puncture biopsy. }\end{array}$ \\
\hline Dhote et al. $1996^{[16]}$ & France & 1 & $\begin{array}{l}\text { Patient had a history of right-sided sciatica } \\
\text { associated with her menses secondary to } \\
\text { right ovarian cystic endometriosis that } \\
\text { compressed the right sciatic nerve. }\end{array}$ & $\begin{array}{l}\text { Physical examination, including neurologic } \\
\text { and spine evaluation, radiographs, CT and } \\
\text { pelvic MRI. }\end{array}$ \\
\hline Khodairy et al. $1995^{[17]}$ & Switzerland & I & $\begin{array}{l}\text { A 38-year-old woman complained of } \\
\text { right-sided sciatic pain from an enlarged, } \\
\text { retroverted adenomyotic uterus. }\end{array}$ & MRI and echography. \\
\hline Takata et al. $1994^{[18]}$ & Japan & I & $\begin{array}{l}\text { Patient had a history of right-sided peculiar } \\
\text { sciatica associated with her menses } \\
\text { secondary to intrapelvic endometrioma. }\end{array}$ & $\begin{array}{l}\text { Neurologic examination, CT, CA- } 125 \\
\text { levels. }\end{array}$ \\
\hline Bergqvist et al. $1987^{[19]}$ & Sweden & I & $\begin{array}{l}\text { Patient had a history of right-sided } \\
\text { sciatica secondary to endometriosis in } \\
\text { the uterosacral ligament compressing of } \\
\text { the sciatic nerve. }\end{array}$ & $\begin{array}{l}\text { The neurologic, orthopedic, gynecologic } \\
\text { examination, aspiration biopsy. }\end{array}$ \\
\hline Andrews et al. $1987^{[20]}$ & USA & I & $\begin{array}{l}\text { Patient had an intrapelvic tuba ovarian } \\
\text { abscess presenting as sciatica. }\end{array}$ & $\begin{array}{l}\text { Neurologic examination, CT, gynecologic } \\
\text { examination, cervical cultures. }\end{array}$ \\
\hline Björnsson et al. $1976^{[21]}$ & England & I & $\begin{array}{l}\text { A } 27 \text {-year-old woman with right-sided } \\
\text { cyclic sciatica and stiffness of the right hip } \\
\text { joint. }\end{array}$ & $\begin{array}{l}\text { Orthopedic examination and an } \\
\text { exploratory laparotomy. }\end{array}$ \\
\hline Head et al. $1962^{[22]}$ & USA & I & $\begin{array}{l}\text { Patient had a history of right-sided } \\
\text { sciatica secondary to intrapelvic sciatic } \\
\text { endometriosis. }\end{array}$ & $\begin{array}{l}\text { Physical examination, EMG, myelographic } \\
\text { examination. }\end{array}$ \\
\hline
\end{tabular}

radiologist should concern specific MRI sequences of the intrapelvic portion of the sacral plexus, and a team should be prepared to expose and decompress the sacral nerves.

\section{Sciatic nerve and/or sacral nerve root endometriosis}

Possover et al. ${ }^{[3]}$ reported neurologic follow-up of patients after extensive laparoscopic resection of deep infiltrating endometriosis of the intrapelvic part of the sciatic nerve. In this study, 46 patients underwent an extensive resection of the sciatic nerve (more than $30 \%$ of the nerve) and were followed for at least five years. All patients presented preoperatively with incapacity for normal gait, drop foot and intractable and constant neuropathic sciatic pain with sensorimotor disorders of the affected leg. The most frequent resected portion of the sciatic nerve was the cranial part that corresponds to the roots of the nerve L5, SI $( \pm S 2)$, while the middle portion and the caudal portion of the sciatic nerve were less involved.

Significant functional recovery and pain scores occurred in most patients after 2,5 to 3 years, while normal gait function was obtained 4 to 5 years after the procedure. Possover et al. ${ }^{[3]}$ demonstrated that laparoscopic neurosurgery for treating deep infiltrating endometriosis of the sciatic nerve might be reserved only for experienced surgeons in laparoscopic retroperitoneal pelvic surgery. When full resection of endometriosis, including nerve resection, was completed, sciatic nerve functions recover, and normal gait could take at least three years with intensive physiotherapy. Lemos et al. ${ }^{[7]}$ reported perimenstrual urinary retention and intense right-sided sciatica in a 38-year-old woman patient. MRI showed only posterior cul de sac obliteration, but neurologic examination suggested compression of sacral dermatomes. Laparoscopic exploration of the sacral nerve roots demonstrated vascular compression of the lumbosacral trunk and endometriosis entrapping the S2 to S4 sacral nerve roots, endometrioma inside S3. The endometriosis was removed from the sacral nerve roots and detached from the sacral bone. The regular urinary function was restored on postoperative day 2 , and the pain was resolved after a period of post-decompression. Zager et al. ${ }^{[14]}$ described catamenial mononeuropathy and radiculopathy in five patients 
Table 2. Surgical procedures and clinical outcomes of studies included in this review

\begin{tabular}{ll}
\hline Authors & Surgical procedures \\
\hline Lemos et al. 20I9[1] & $\begin{array}{l}\text { All cases had a variant superior gluteal vein that was } \\
\text { ligated intraoperatively. }\end{array}$ \\
Kale et al. 2019[2] & $\begin{array}{l}\text { Laparoscopic decompression of intrapelvic aberrant } \\
\text { dilated veins at three sites: the lumbosacral trunk, sciatic } \\
\text { nerve, and pudendal nerve. The aberrant dilated veins } \\
\text { were gently dissected from nerves and then coagulated } \\
\text { and cut with the LigaSure sealing device. }\end{array}$
\end{tabular}

Possover et al. 2017[3] All procedures were performed laparoscopically. The most frequent resected portion of the sciatic nerve $(n=38)$ was the cranial part that corresponds to the roots of the nerve L5, SI $( \pm S 2)$. The middle portion $(n=6)$ and the caudal portion $(n=2)$ of the sciatic nerve were less involved.

Tsai et al. 2016 ${ }^{[4]} \quad$ The patient underwent laparoscopic broad ligament myomectomy. The tumor was diagnosed as a large $93 \times 58 \times 40 \mathrm{~mm}$ leiomyoma with no significant surrounding non-neoplastic tissue.

Lemos et al. $2016^{[5]} \quad$ Two laparoscopic decompressions of intrapelvic aberrant dilated veins on the sciatic nerve and one on the sacral nerve roots.

Possover et al. 2015[6] All cases had atypical superior and inferior gluteal varicose veins that were separated, coagulated and transected.

Lemos et al. 2012 $2^{[7]} \quad$ Laparoscopic exploration of the sacral nerve roots demonstrated vascular compression of the lumbosacral trunk and endometriosis, entrapping the $\mathrm{S} 2$ to $\mathrm{S} 4$ sacral nerve roots, and an endometrioma inside $\mathrm{S} 3$. The endometriosis was removed from the sacral nerve roots and detached from the sacral bone.

Tong et al. $2003^{[8]} \quad$ Laparotomy via Pfannenstiel incision was performed. At surgery, the $2.9 \times 2.2 \mathrm{~cm}$ presacral schwannoma corresponding to the first sacral nerve was found deep in the pelvis adjacent to the right sciatic notch. It was excised completely.

Vilos et al. $2002^{[9]} \quad$ All of these patients ultimately required laparoscopic procedures. Findings at laparoscopy included pelvic peritoneal pockets in 15 patients, peritoneal endometriosis in 5 and endometriosis nodules $(\mathrm{I}-4 \mathrm{~cm})$ in 5 . All these lesions were located in the posterolateral pelvic peritoneum and were excised.

Murata et al. 200|[10] The patient underwent an abdominal hysterectomy operation. The uterus was mildly adherent to the sacrum with a marked indentation on its posterolateral surface.

Fedele et al. 1999[1]] No surgical approach.

After laparoscopic intrapelvic sciatic nerve endometriosis resection was completed, sciatic nerve motoric functions recovery took at least three years, and intensive physiotherapy was needed to recover a normal gait.

After the operation, left sciatic pain disappeared.

After surgery, the patient with the sciatic entrapment showed full recovery of sciatica and partial recovery of the myofascial pain. The patient with sacral nerve root entrapment showed full recovery with resolution of symptoms.

Laparoscopic decompression by atypical superior and inferior gluteal varicose veins resulted in symptomatic improvement.

After surgery, the normal urinary function was restored on postoperative day 2, and pain resolved after a period of postdecompression.

The patient had an uneventful postoperative recovery with no neurological complications via laparotomy route with complete resolution of symptoms after 6 months of surgery.

After laparoscopic excision, sciatic symptoms were eliminated in 19, markedly improved in 4 , remained the same in two, and recurred in three patients after two years.

After the operation, the sciatic pain disappeared, with a gradual return of motor function. No recurrence was apparent on review at 16 months.

These patients underwent monthly administration of the $\mathrm{GnRH}-\mathrm{a}$ leuprolide acetate plus daily transdermal E2 $(25 \mathrm{mg})$. After medical treatment, pain symptoms relieved, and motor functions improved. 
Table 2. Surgical procedures and clinical outcomes of studies included in this review (continue)

\begin{tabular}{ll}
\hline Authors & Surgical procedures \\
\hline Siera et al. 1999[12] & No surgical approach. \\
Bodack et al. 1999[13] & The patient underwent a subtotal abdominal hysterectomy. \\
Zager et al. 1998[14] & $\begin{array}{l}\text { Each of these patients ultimately required laparoscopic } \\
\text { surgical procedures. Pathological examination proved the } \\
\text { tumor to be an endometrial tissue deposit involving the } \\
\text { sciatic nerve, femoral nerve and sacral nerve roots. } \\
\text { Ortolan et al. 1996[15] }\end{array}$ \\
$\begin{array}{l}\text { Surgery was performed through a posterior midline } \\
\text { incision. The tumor as a brown lobular soft mass } \\
\text { was eroded in the posterior aspect of SI, S2 and L5. } \\
\text { After unroofing the sacrum and performing L5 right } \\
\text { laminectomy, the complete posterior tumoral mass was } \\
\text { removed completely. } \\
\text { Surgical exploration of the retroperitoneal space } \\
\text { confirmed the presence of a right ovarian endometriotic } \\
\text { cyst that was compressing the right sciatic nerve. It was } \\
\text { excised completely. The rest of the pelvis was normal. }\end{array}$ \\
Dhote et al. 1996[16]
\end{tabular}

Khodairy et al. 1995[17] The patient underwent a total abdominal hysterectomy. Histopathology confirmed adenomyosis of the uterus.

Takata et al.1994[18] No surgical approach.

Bergqvist et al. $1987^{[19]}$ From an incision parallel to the inguinal ligament, an extraperitoneal approach was used. The endometriotic lesion was excised without opening the vagina.

Andrews et al. 1987 $7^{[20]} \quad$ No surgical approach.

Björnsson et al. 1976 ${ }^{[21]} \quad$ Exploratory laparotomy revealed pelvic endometriosis.

Head et al. 1962 $2^{[22]} \quad$ Laparotomy via Pfannenstiel incision was performed at the surgery. As much endometriosis could be safely excised on the first sacral nerve without rendering further permanent damage to the sciatic nerve.

\section{Clinical outcomes}

The patient underwent depot medroxyprogesterone treatment. After medical treatment, pain symptoms disappeared. After the operation, pain symptoms disappeared.

After the surgery, pain and sensory symptoms responded well to therapy.

Posterior midline incision and excision of giant schwannoma on the sacrum resulted in symptomatic improvement after 17 months of surgery.

After surgery, gonadotropin-releasing hormone therapy was begun and continued for 6 months. The patient was examined I year after the operation, and it was confirmed that she remained active, free of pain and experienced menses without sciatica.

Six months after the operation, the patient was symptom-free.

The patient underwent hormonal therapy by nose dropping of buserelin acetate, completely relieved of right sciatic pain.

The patient had an uneventful postoperative recovery.

The patient underwent a 3-week course of intravenous antibiotics (gentamicin and clindamycin) with marked improvement of right sciatic pain.

On estrogen suppression therapy, the patient has been symptom-free for eleven months.

The patient had an uneventful postoperative recovery five months of surgery. whose symptoms included pain, weakness and sensory deficit.

Postoperatively pain and sensory symptoms responded dramatically well to therapy. Zager et al. ${ }^{[14]}$ stated that early recognition and treatment of this disorder was essential to minimize the severity of nerve damage caused by the recurrent cycles of hemorrhage and fibrosis that are characteristics of endometriosis. Fedele et al. ${ }^{\left[{ }^{\prime I}\right]}$ assessed GnRH-A therapy's efficacy and diagnostic value in cases of hidden sciatic nerve endometriosis in three patients and proved by clinical response to $\mathrm{GnRH}-\mathrm{A}$ treatment with a relief of pain symptoms and improvement in motor function. Fedele et al. ${ }^{\left[{ }^{\prime \prime}\right]}$ concluded that sciatic nerve endometriosis should always be considered in women with catamenial sciatica. A prompt medical treatment institution to suppress gonadal activity permits confirmation of the diagnosis, prevents disease progression, and avoids inappropriate neurosurgical procedures that may cause permanent lesions. Sierra et al. ${ }^{[12]}$ described bilateral intrapelvic cyclic sciatica due to the implantation of endometrial tissue in the sciatic nerve in the sciatic notch region. The patient was being treated with depot medroxyprogesterone, and 
her pain disappeared. The use of depot medroxyprogesterone seemed to be a satisfactory treatment in some patients for the implantation of endometrial tissue in the sciatic nerve. Head et al. ${ }^{[2]}$ reported a woman complained of pain resembling sciatica, which recurred over more than four years in a certain time-relation to the menstrual cycle. Electromyography revealed denervation of muscles supplied by nerve roots L5 and SI. An exploratory operation revealed small dark nodules adhering to the intrapelvic part of the sciatic nerve. Excision of the nodules and subsequent irradiation were followed by the complete disappearance of the leg's cyclic pain.

\section{Pelvic endometriosis and/or endomerioma}

Vilos et al. ${ }^{[9]}$ determined laparoscopic findings, management, histopathology and outcomes in 25 women with cyclic leg pain and found endometriotic nodules in five, peritoneal pockets and, or peritoneal endometriosis in 19, and inflammatory peritoneum in one woman. Associated pelvic endometriosis was identified and confirmed in 17 women (68\%). They hypothesized that cyclic leg pain was associated with pelvic peritoneal pockets, endometriosis nodules, or surface endometriosis of the posterolateral pelvic peritoneum. This was more likely referred to pain originating from the pelvic peritoneum than direct irritation of the lumbosacral plexus of the sciatic nerve. Dhôte et al. ${ }^{[16]}$ reported a case of cyclic sciatica secondary to ovarian endometrioma at the right sciatic notch. Surgical exploration of the pelvic retroperitoneal space confirmed the right ovarian endometrioma was compressing the right sciatic nerve. One year after the operation and GnRH-A therapy, the patient remained free of sciatica. Takata et al. ${ }^{[18]}$ reported a case of endometrioma in the pelvic cavity with periodic sciatalgia associated with menses. Computed tomography indicated an oval-shaped mass compressing the right sciatic nerve. Right-sided sciatic pain was wholly relieved after buserelin acetate treatment. Takata et al. ${ }^{[18]}$ emphasized the importance of suspecting lesions when sciatica presents are closely related to menses. Bergqvist et al. ${ }^{[19]}$ founded endometriosis in the uterosacral ligament compressing of the sciatic nerve treated via an extraperitoneal approach keeping the pelvic organs intact. The pain disappeared utterly immediately postoperatively, and she has been without complaints after the operation. Björnsonn et al. ${ }^{[21]}$ reported a 27-year-old woman with right-sided cyclic sciatica due to pelvic endometriosis. She had been symptom-free for eleven months after estrogen suppression therapy.

\section{Pelvic schwannoma}

Tong et al. ${ }^{[8]}$ reported right-sided sciatica secondary to retroperitoneal pelvic schwannoma. Surgical excision of presacral schwannoma corresponded to the first sacral nerve relieving symptoms without neurological complications. They stated that pelvic schwannoma is a rare cause of sciatica, which has an excellent prognosis after surgical resection. Ortolan et al. ${ }^{[15]}$ reported large sacral schwan- nomas with anterior cortex erosion associated with an intrapelvic extension. Surgery was performed after unroofing the sacrum and performing laminectomy. Symptomatic improvement after 17 months of surgery was achieved. Ortolan et al. ${ }^{[15]}$ stated that based on the experiences of the few cases that had been reported, the management of pelvic schwannoma appeared to grant favorable results despite frequent recurrence complications.

\section{Gynecologic pathologies}

Tsai et al. ${ }^{[4]}$ reported a postmenopausal woman with sciatica from broad ligament leiomyoma. The patient underwent laparoscopic myomectomy; the $93 \times 58 \times 40 \mathrm{~mm}$ leiomyoma originated from the uterus's left broad ligament. On pathologic examination of the specimen, the tumor was diagnosed as a leiomyoma. After the operation, the left sciatic pain disappeared. Murata et al. ${ }^{[10]}$ described a 47-year-old woman with sciatic neuropathy caused by compression of the uterus's sacral plexus, which also had a small myoma-like lesion. The patient underwent an abdominal hysterectomy operation. After the operation, the sciatic pain disappeared, with a gradual return of motor function. Bodack et al. ${ }^{[13]}$ reported sciatic neuropathies secondary to the uterine fibroid. The patient underwent a subtotal abdominal hysterectomy, with a resolution of sciatica pain. Khodairy et al. ${ }^{[17]}$ reported a 38-year old woman who complained of right-sided sciatic pain from an enlarged retroverted adenomyotic uterus. The patient underwent a total abdominal hysterectomy. Histopathology confirmed adenomyosis of the uterus. Six months after the operation, the patient was symptom-free. Andrews et al. ${ }^{[20]}$ reported tuba ovarian abscess presenting as sciatic pain. The patient underwent a 3-week course of intravenous antibiotics (gentamicin and clindamycin) with marked improvement of her right sciatic pain. All these authors, ${ }^{[4,10,13,17]}$ stated that sciatica might be the main presenting feature of adenomyosis, myoma uteri, and tuba ovarian abscess.

\section{DISCUSSION}

This systematic review aims to evaluate intrapelvic pathologic conditions along the sciatic nerve that may cause sciatica. Some intraspinal or extraspinal pathologies may also induce sciatica. Extraspinal sciatic nerve entrapment presents with radicular pain of the lower back radiating to the buttock, worsening with sitting, resulting in paresthesia of the affected leg. ${ }^{[1-3]}$ Intrapelvic lesions lying within the deep gluteal space can be a reason for sciatica, as well. ${ }^{[2,6,7]}$ Detection of the intrapelvic sciatic nerve entrapment level is essential for managing sciatica pain. Intrapelvic sciatic nerve entrapment diagnosis begins with a detailed physical and neuropelveologic examination, including dermatomal mapping of pain and paresthesia and assessing reflexes. A neurological examination and neuro MRI may be necessary to exclude lumbar disc diseases. Intrapelvic neurovascular compression in symptomatic patients is likely under-diagnosed. According to data, sciatic pain related to aberrant 
intrapelvic vein treated by laparoscopic decompression was identified in 27 patients. $^{[1,2,5,6]}$ Therefore, dilatation of these vessels may entrap the sciatic nerve against the pelvic sidewalls and result in sciatica. The most common area reported is at L5-SI/2 nerve root compression at the greater sciatic notch. ${ }^{[6]}$ Laparoscopic decompression is a therapeutic choice based on the separation of the irritating vessel from the nerves. This is a safe method with high success rates, and the results are directly correlated with the detailed preoperative neuropelveological examination. ${ }^{[1,2,6,7]}$

Endometriosis infiltrating the sacral nerves or sciatic nerve is a rare pathology - the first description of this entity was present in 1955. ${ }^{[3,7]}$ Awareness of pelvic sciatic nerve endometriosis has increased over the last few years. Sciatic endometriosis is uncommon but should always be kept in mind, especially sciatic pain that worsens during the menstrual period in the absence of spinal conditions. The vital clinical symptoms in intrapelvic sciatic nerve endometriosis are sciatica, buttock and hip pain, voiding dysfunction of the bladder and urinary urgency. ${ }^{[3,7,14,22]}$ Laparoscopic surgery is a surgical choice for treating sciatic or sacral nerve root endometriosis. However, when full resection of sciatic or sacral nerve roots endometriosis is completed, sciatic nerve function recovery may take at least three years, and intensive physiotherapy is needed to recover a normal gait. ${ }^{[3,7,14,22]}$ The use of depot medroxyprogesterone or $\mathrm{GnRH}-\mathrm{A}$ leuprolide acetate plus daily transdermal E2 $(25 \mathrm{mg}$ ) therapy appears to be a satisfactory treatment in some patients with sciatic endometriosis. ${ }^{[11,12]}$

Schwannomas (neurilemmomas) are benign neural sheath tumors. Pelvic schwannomas are exceptional and correspond to less than I\% of all benign schwannomas. Pelvic schwannomas often present with non-specific symptoms, leading to misdiagnosis and prolonged morbidity due to diagnosis delay. Most pelvic schwannomas are located in the presacral space presenting as a pelvic mass. ${ }^{[8,15]}$ Pelvic schwannoma cases are manifested with sciatica pain radiating down the hips, leg, and calf muscle to the foot. With MRI, the preoperative diagnosis of pelvic schwannomas is possible. Surgical resection of pelvic schwannomas is a curative treatment. Pelvic schwannomas theoretically are resectable with ease and can be "shelled out" of the capsule. Pelvic schwannomas have an excellent prognosis after surgical resection. ${ }^{8,15]}$

Endometriosis is characterized by endometrial-like tissue outside the uterus. Cyclic leg pain or sciatica pain symptoms are related to peritoneal pelvic endometriosis, endometriotic nodules, endometriotic cysts and uterosacral endometriosis. The pain associated with these lesions is more probably to originate from the pelvic peritoneum and the lumbosacral plexus's direct irritation. Surgical excision of endometriotic lesions frequently alleviates sciatica symptoms. ${ }^{[9,16,19,21]}$ Buserelin acetate therapy or estrogen suppression therapy seems to be a gratifying treatment in some patients with sciatic endometriosis. ${ }^{[18,21]}$

A minority of sciatica cases connected to gynecological diseases have been reported. Leiomyomas, adenomyosis and tuba ovarian abscess are associated with sciatica-like symptoms. Leiomyomas are the most common female benign genital neoplasm of the uterus, affecting $30 \%$ of women of reproductive age. An unexpected cause of sciatica pain may be compression of sacral nerve roots by the uterine fibroids, uterine adenomyosis and tuba ovarian abscess. Surgical interventions, such as myomectomy, adenomyomectomy, hysterectomy, tuba ovarian abscess drainage or medical treatment of tuba ovarian abscess, may relieve intrapelvic sciatica symptoms. ${ }^{[4,10,13,17,20]}$

\section{CONCLUSION}

Depending on current reports, we knew that intrapelvic cause of sciatica, such as aberrant intrapelvic veins, sciatic nerve or sacral nerve root endometriosis, pelvic endometriosis or endometrioma, pelvic schwannoma, and gynecologic pathologies could be the etiology. The symptoms; suggesting an intrapelvic cause of sciatica are perineal pain or pain radiating to the lower limbs in the non-existence of spinal disorders. After a detailed assessment of the patient, surgery or medical therapy can be administered with excellent sciatica pain remission results.

\section{Peer-review}

Internally peer-reviewed.

\section{Authorship Contributions}

Concept: A.K., G.B., B.K.; Design: A.K., T.A.U., G.Y., N.D.U.; Supervision: A.K., T.U.; Materials: A.K., G.B., E.C.G., E.M.; Data: E.M., G.Y., G.B., E.C.G.; Analysis: N.D.U., G.B., A.K., G.Y.; Literature search: N.D.U., E.M., G.Y., B.K.; Writing: A.K., G.B., E.C.G., E.M.; Critical revision: A.K., T.A.U., B.K.

\section{Conflict of Interest}

None declared.

\section{REFERENCES}

1. Lemos N, Cancelliere L, Adrienne LKL, Marques RM, Gustavo LF, Sermer C, et al. Superior gluteal vein syndrome: an intrapelvic cause of sciatica. J Hip Preserv Surg 2019;6:104-8. [CrossRef]

2. Kale A, Basol G, Usta T, Cam I. Vascular entrapment of both the sciatic and pudendal nerves causing persistent sciatica and pudendal neuralgia. J Minim Invasive Gynecol 2019;26:360-1. [CrossRef]

3. Possover M. Five-year follow-up after laparoscopic large nerve resection for deep infiltrating sciatic nerve endometriosis. J Minim Invasive Gynecol 2017;24:822-6. [CrossRef]

4. Tsai YM. A postmenopausal woman with sciatica from broad ligament leiomyoma: a case report. J Med Case Rep 2016;10:304. [CrossRef]

5. Lemos N, Marques RM, Kamergorodsky G, Ploger C, Schor E, Girão MJBC. Vascular entrapment of the sciatic plexus causing catamenial sciatica and urinary symptoms. Int Urogynecol J 2016;27:317-9.

6. Possover M, Forman A. Pelvic neuralgias by neurovasculer entrapment: Anatomical findings in a series of 97 consecutive patients treated by laparoscopic nerve decompression. Pain Physician 2015;18:1139-43. [CrossRef]

7. Lemos N, Kamergorodsky G, Ploger C, Castro R, Schor E, Girão $\mathrm{M}$. Sacral nerve infiltrative endometriosis presenting as perimenstrual right-sided sciatica and bladder atonia: case report and description of 
surgical technique. J Minim Invasive Gynecol 2012;19:396-400.

8. Tong RS, Collier N, Kaye AH. Chronic sciatica secondary to retroperitoneal pelvic schwannoma.J Clin Neurosci 2003;10:108-11. [CrossRef]

9. Vilos GA, Vilos AW, Haebe JJ. Laparoscopic findings, management, histopathology, and outcome of 25 women with cyclic leg pain. J Am Assoc Gynecol Laparosc 2002;9:145-51. [CrossRef]

10. Murata $Y$, Takahashi K, Murakami M, Moriya $\mathrm{H}$. An unusual cause of sciatic pain. J Bone Joint Surg Br 2001;83:112-3. [CrossRef]

11. Fedele L, Bianchi S, Raffaelli R, Zanconato G, Zanette G. Phantom endometriosis of the sciatic nerve. Fertil Steril 1999;72:727-9. [CrossRef]

12. Calzada-Sierra DJ, Hernández EF, Prieto RV, Fernández LG, Santana de la Fé A. Bilateral cyclic sciatica caused by endometriosis. Apropos of a case. Rev Neurol 1999;29:34-6. [CrossRef]

13. Bodack MP, Cole JC, Nagler W. Sciatic neurapthy secondary to a uterine fibroid: a case report. Am J Phys Med Rehabil 1999;78:157-9.

14. Zager EL, Pfeifer SM, Brown MJ, Torosian MH, Hackney DB. Catamenial mononeuropathy and radiculopathy: a treatable neuropathic disorder. J Neurosurg 1998;88:827-30. [CrossRef]

15. Ortolan EG, Sola CA, Gruenberg MF, Vazquez FC. Giant sacral schwannoma. A case report. Spine (Phila Pa 1976) 1996;21:522-6.
16. Dhôte R, Tudoret L, Bachmeyer C, Legmann P, Christoforov B. Cyclic sciatica. A manifestation of compression of the sciatic nerve by endometriosis. A case report. Spine (Phila Pa 1976) 1996;21:2277-9.

17. Khodairy AT, Gerber BE, Praz G. Adenomyosis-- an unusual cause of sciatic pain. Eur Spine J 1995;4:317-9. [CrossRef]

18. Takata K, Takahashi K. Cyclic Sciatica: A case report. Spine (Phila Pa 1976) 1994;19:89-90. [CrossRef]

19. Bergqvist A, Bergqvist D, Lindholm K, Linell F. Endometriosis in the uterosacral ligament giving orthopedic symptoms through compression of the sciatic nerve and surgically treated via an extraperitoneal approach keeping the pelvic organs intact. Acta Obstet Gynecol Scand 1987;66:93-4. [CrossRef]

20. Andrews DW, Friedman NB, Heier L, Erickson A, Lavyne MH. Tuboovarian abscess presenting as sciatic pain: case report. Neurosurgery 1987;21:100-3. [CrossRef]

21. Björnsoon OG. Cyclic sciatica of endometriosis. Case report. Acta Chir Scand 1976;142:415-6.

22. Head HB, Welch JS, Mussey E, Espinosa RE. Cyclic sciatica. Report of case with introduction of a new surgical sign. JAMA 1962;180:521-4. [CrossRef]

\section{Siyataljinin İntrapelvik Nedenleri: Sistematik Bir Derleme}

Siyatik sinir, alt ekstremitenin bir siniridir. Spinal sinirlerden; dördüncü Lomber’den (L4) üçüncü Sakral'a (S3) kadar olan sinir köklerinin birleşmesi ile oluşur. Siyatik sinir, arka uyluk kaslarını innerve eder ve ek olarak duyusal fonksiyonu vardır. Siyatalji, siyatik sinirin irritasyonundan kaynaklanan ağrıya verilen isimdir. Siyatalji en yaygın olarak alt lomber sinir köklerinin (L4, L5 veya SI) sıkışması ile indüklenir. Jinekolojik, vasküler, travmatik, enflamatuvar ve tümöral bozukluklar gibi çeşitli intrapelvik patolojiler siyataljiye neden olabilir. Disk herniasyonunu taklit eden intrapelvik patolojiler çoğunlukla göz ardı edilir. Cerrahi yaklaşım ve laparoskopi veya robotik cerrahi ile fonksiyonel keşif, siyataljiye neden olabilen intrapelvik patolojilerin farkındalığını önemli ölçüde arttırmıştır. Hastanın intrapelvik patolojilere açısından detaylı incelenmesinin ardından cerrahi veya medikal tedavi gerekliliğine karar verilir; siyatik ağrı remisyonunda kayda değer sonuçlar alınabilir.

Anahtar Sözcükler: Aberran damar; endometriozis; jinekolojik operasyon; pelvik ağrı; siyatalji; siyatik sinir; vasküler kompresyon. 